\title{
ULTRASTRUCTURAL LOCALIZATION OF HEPATITIS C VIRUS POSITIVE AND NEGATIVE STRAND RNA AND PROTEINS IN HEPATOCYTES OF A RHESUS MONKEY (MACACA MULATTA).
}

Selma Majerowicz ${ }^{1}$, Christopher Grief ${ }^{1,2}$, Marcelo Alves Pinto ${ }^{1}$, Marcia Leite Baptista ${ }^{1}$, Angela Teixeira Pinhão ${ }^{1}$, Renata Cristina Airano ${ }^{1}$, Cláudia Lamarca Vitral ${ }^{3}$, Renato Sergio Marchevsky ${ }^{4}$, Clara FT Yoshida ${ }^{1}$ and Ortrud Monika Barth ${ }^{1}$

\footnotetext{
${ }^{1}$ Instituto Oswaldo Cruz, Fiocruz, Rio de Janeiro, Brazil.

${ }^{2}$ NIBSC, Potters Bar, Herts, EN6 3QG, Inglaterra.

${ }^{3}$ Instituto Biomédico, Universidade Federal Fluminense, Niterói, Brazil.

${ }^{4}$ Instituto de Tecnologia em Imunobiológicos, Fiocruz, Rio de Janeiro, Brazil.
}

Corresponding author:

Laboratório de Morfologia e Morfogênese Viral, Instituto Oswaldo Cruz, Fiocruz, Avenida Brasil 4365, 21040-900 Rio de Janeiro, Brazil.

Tel.: +55 $212562-1707$

Fax: +55 $212260-4866$

E-mail: $\underline{\text { selmam@ioc.fiocruz.br }}$

Key words: rhesus monkey, hepatitis $\mathrm{C}$ virus, ultrastructure, in situ hybridization, viral proteins, replication complex 


\section{ABSTRACT}

Morphological alterations of the liver from rhesus macaque (Macaca mulatta) experimentally infected with hepatitis $\mathrm{C}$ virus (HCV) were analyzed using electron microscopy. The localization of viral RNA and proteins inside hepatocytes was demonstrated using in situ hybridization and immunoelectron microscopy techniques. The animals were inoculated by different routes. The infection was successful only by use of the intrasplenic approach to HCV infected autogenic hepatocyte transplant. The inoculum used to infect the hepatocytes was characterized as genotype 3 with $10^{7}$ RNA copies/mL. In situ hybridization was performed using a complementary negative and positive strand probe made with the specific primer. Despite that the level of HCV infection was considered to be low, we were able to detect and localize viral positive and negative RNA strands and viral proteins in altered membranes of the rough endoplasmic reticulum in infected liver cells, showing evidence of viral replication in vivo.

\section{INTRODUCTION}

Hepatitis C virus (HCV), a major cause of chronic hepatitis, may lead to cirrhosis and to hepatocellular carcinoma (Houghton 1996). Identified only after the development of recombinant DNA technology (Choo et al. 1989), the HCV contains a positive stranded RNA genome and has been classified as a Hepacivirus within the Flaviviridae family. The viral RNA, after entry into the cell is liberated into the cytoplasm and translated to a large polyprotein that is cleaved by action of cellular (Penin et al. 2004) and viral proteases (NS2/3 protease and NS3 serine protease) into the structural proteins, which consist of capsid protein (core) and envelope proteins (E1, E2), the hydrophobic peptide P7 and the nonstructural proteins NS2, NS3, NS4A, NS4B, NS5A, NS5B. The interactions that occur between HCV proteins and intracellular membranes showed their essential role in virus replication (Debuisson et al. 2002, Salonen et al. 2004). The replication of positive-strand RNA viruses is associated with modified cytoplasmic membranes which provide an environment for RNA replication and assembly of viruses (Solonen et al. 2004, Novoa et al. 2005). The proteins of HCV form a complex tightly associated with endoplasmic reticulum membranes (Egger et al. 2002), where the plus-strand RNA genome is copied into a minus-strand RNA 
intermediate, that serves as a template for the synthesis of excess amounts of plus-strand RNA molecules which are encapsulated forming virions or serving as mRNAs for viral protein synthesis (Bartenschlager \& Lohmann 2000, Pawlotsky 2004). Recent reports considered the presence of negative strand RNA HCV as indicative of viral replication and its correlation with cytological alterations in human liver (Chang et al. 2000, Quadri et al. 2001, Falcón et al. 2003, Yuki et al. 2006). HCV do not replicate easily in cell cultures, and the infection titer in vivo is usually quite low; consequently, details about its replication cycle, both in vivo and in vitro, are not completely understood. The detection of HCV minus-strand RNA in experimentally infected chimpanzee liver was shown by reverse transcription/ polymerase chain reaction (RT-PCR) (Shimizu et al. 1998). In situ hybridization studies of the genomic RNA have been revealed in chimpanzee hepatocytes by immunohistochemical reaction (Negro et al. 1992). In addition, some reports described the detection of HCV RNA minus-strand in human liver by in situ hybridization technique also, not showing the ultrastructural localization of HCV RNA (Lamas et al. 1992, Nouri-Aria et al. 1993, Gastaldi et al. 1995, Sansonno et al. 1997, Chang et al. 2000). Shimizu et al. (1996) observed a positive reaction in the liver biopsies of $\mathrm{HCV}$ infected chimpanzees, using the immunofluorescence technique with anti-HCV envelope protein. Ultrastructural observations of hepatocytes of chimpanzee and human liver biopsies showed the HCV core protein localized around lipids droplets and endoplasmic reticulum membranes (Barba et al. 1997, Falcón et al. 2003). Since the development of HCV replicons capable of replication in a human hepatoma Huh-7 cell line (Lohmann et al. 1999) was realized, several studies of HCV morphogenesis were published. Using electron microscope observation, immunolabelling of Huh-7 cells harboring a subgenomic HCV replicon showed HCV non-structural proteins (Pietschmann et al. 2001, Mottola et al. 2002, Moradpour et al. 2003, Gosert et al. 2003, Moradpour et al. 2004), structural proteins (Pietschmann et al. 2002) and viral plus-strand RNA (Gosert et al. 2003) in altered membranes of the endoplasmic reticulum, designated the membranous web (Egger et al. 2002), and suggesting that this structure was the site of viral RNA synthesis representing the replication complex of HCV (Gosert et al. 2003). The aim of the present study is to characterize the intracellular localization of the positive and negative HCV RNA strands and the viral proteins inside the liver tissue of $\mathrm{HCV}$ infected rhesus monkeys at the ultrastructural level of resolution for a better understanding of HCV replication in vivo. 


\section{Materials and Methods}

\section{Animals.}

Six clinically healthy adult rhesus primates (Macaca mulatta), non-reactive for $\mathrm{HCV}$ antibodies, provided by the Primatology Department of the Center for Laboratory Animal Breeding of the Fundação Oswaldo Cruz, Rio de Janeiro, Brazil, were included in the study. They showed normal levels of alanine aminotransferase (ALT) and aspartate aminotransferase (AST) liver enzymes. Environmental conditions included temperature of $22-24^{\circ} \mathrm{C}$, relative humidity of $60 \%$, exposition to light for 12 hours per day. The animals were feeded with commercial food and water ad libitum, housed in individual cages, and cared according to biosafety level 2 precautions and procedures outlined in compliance with the Ethical Committee for Animal Research (CEUA/Fiocruz: P-0013/00).

\section{Inoculum.}

The serum sample used in the present experiment was chosen among human patients presenting an acute and early phase of $\mathrm{HCV}$ infection. The criterium of choice was based on the highest viral load and poor antibody response, so that a serial testing was performed on the samples of alanine aminotransferase, anti-HCV, and HCV RNA. $\mathrm{HCV}$ antibodies were tested through a third generation enzyme immune assay (EIA) (Abbott) and qualitative and quantitative HCV RNA detection through a real time PCR. The protocol of procedures was submitted to the Human Research Committee of the Oswaldo Cruz Foundation and reviewed by the Institutional Review Board. The clinicbased acute hepatitis $\mathrm{C}$ cases (jaundice and with elevated serum aminotransferase level) were submitted to clinical evaluation and had blood samples collected at the National Reference Laboratory of Viral Hepatitis (NRLVH) / Oswaldo Cruz Foundation, Rio de Janeiro, Brazil. Finally, the inoculum was characterized by PCR (Cobas Amplicor) as HCV positive RNA, genotype 3 and quantified as $10^{7}$ RNA copies $/ \mathrm{mL}$.

\section{Electron microscopy.}

Epon embedding.

Liver tissue biopsies were fixed with $2 \%$ glutaraldehyde in $0.06 \mathrm{M}$ sodium

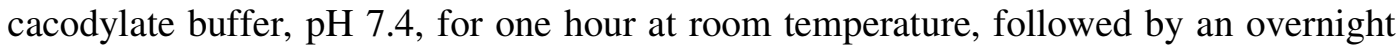
period at $4^{\circ} \mathrm{C}$. They were dehydrated in graded acetone and embedded in Epon resin. 
Ultra-thin sections were stained with uranyl acetate and lead citrate and examined with a Zeiss EM-900 electron microscope.

Low temperature embedding.

The glutaraldehyde fixed liver samples were dehydrated in increasing concentrations of ethanol using progressively lower temperatures starting with $30 \%$ ethanol followed by $50 \%, 70 \%, 90 \%, 95 \%$ ethanol at $4^{\circ} \mathrm{C}$, and finally two changes of $100 \%$ ethanol at $-20^{\circ} \mathrm{C}$. Samples were then infiltrated and embedded with LR Gold resin containing $0.5 \%$ benzoin methyl ether at $-20^{\circ} \mathrm{C}$. Resin embedded samples were then transferred to pre-cooled resin-filled Beem ${ }^{\circledR}$ capsules and polymerized using ultraviolet irradiation for $24 \mathrm{~h}$ at $-20^{\circ} \mathrm{C}$ followed by $16 \mathrm{~h}$ incubation at room temperature (Grief et al. 1991).

\section{In situ hybridization.}

The methodology developed by Grief et al. (1997) was adapted to performance the electron microscopy in situ hybridization for hepatitis $\mathrm{C}$ virus. The first step in the production of the dig-labelled probes was to isolate HCV RNA from patient serum which was obtained from an HCV positive individual. Viral RNA was isolated by commercial kit (Qia amp viral RNA - Qiagen) and then used for complementary DNA (cDNA) synthesis using a negative sense primer- 5' UTR HCV region 322 to 343 (5' ggt gCA Cgg TCT ACg AgA CC 3'). After cDNA was amplified by PCR using a set 18 to 36 (5' ggC gAC ACT CCA CCA TRR AT 3') and 322 to 343 anti sense synthetic oligonucleotide K-10 and K-11 primers respectively. For nested PCR inner primers were: sense, 38 to 57 (5' ACC ATR RAT CAC TCC CCT gT 3') -K15 primer and antisense 288 to 308 (5' ACC GCA CCC TAT CAg gCA T 3') K16 primer. The PCR consisted of $94^{\circ} \mathrm{C} / 30 \mathrm{~s}$ denaturation step, $50^{\circ} \mathrm{C} / 45 \mathrm{~s}$ annealing step and $72^{\circ} \mathrm{C} / 90 \mathrm{~s}$ elongation step. Both PCR procedures were similar, except for the 25 consecutives cycles used in the nested. Then, new PCR was made and the DNA was labelled with degoxigenin dNTPs during the nested asymmetric PCR. In order to use this DNA to produce single stranded probes, the primers and the uncorporated nucleotides were removed (Qiaquick PCR - Qiagen). The negative strain probe was made with K15 primer and the positive strain probe with K16 primer.

The efficiency of this procedure was confirmed by dot blot hybridization onto a nylon membrane. This was carried out using a four-fold serial dilution of each probe 
(negative and positive).The negative strand probe was detected down to the fifth fourfold dilution while the positive probe was detected down to the third four-fold dilution.

Hybridization - The hybridization mixture was prepared by dilution of the diglabelled HCV probe 1:10 using hibridization buffer, and boiling for 5 minutes prior to use. The hibridization buffer contained: dextran sulphate, MW 55,000 10\% w/v, formamide $50 \% \mathrm{w} / \mathrm{v}$, polyvinylpyrolidone $0.05 \%$, herring sperm DNA $500 \mu \mathrm{g} / \mathrm{mL}$, sodium dodecyl sulphate (SDS) $0.05 \mathrm{w} / \mathrm{v}$, buffer (2xSET) $50 \mathrm{mM}$ Tris-HCl, $300 \mathrm{mM}$ $\mathrm{NaCl}, 2$ mM EDTA pH 7.4.

In situ hybridization at the ultrastructural level was performed on infected and non-infected monkey liver tissue using a 1:10 dilution of the dig-labelled probe.

Ultrathin sections (approximately $75 \mathrm{~nm}$ thick) of LR gold embedded liver tissue were picked up onto acetone-washed 300 mesh hexagonal gold grids. The grids were then immersed into $10 \mu \mathrm{L}$ droplets of the hybridization mixture and incubated for $4 \mathrm{~h}$ at $37^{\circ} \mathrm{C}$, washed by transferring onto 5 droplets of $20 \mathrm{mM}$ Tris buffered saline (TBS) $\mathrm{pH} 7.4$, containing $0.5 \%$ Tween 20 , followed by 5 droplets of $20 \mathrm{mM}$ TBS 7.4. In sequence the grids were incubated for 1 hour at room temperature with a 1:40 dilution of goat anti-digoxigenin antibody conjugated to $10 \mathrm{~nm}$ colloidal gold using a buffer containing $0.2 \mathrm{M}$ Tris- $\mathrm{HCl} \mathrm{pH} 7.4, \mathrm{NaCl} 150 \mathrm{mM}$, fish gelatin $0.1 \%$, Tween $200.5 \%$, bovine serum albumin $1 \%$. The grids were then washed with distilled water and dried before contrast staining for 5 minutes using a $2 \%$ aqueous solution of uranyl acetate.

\section{Immunoelectron microscopy.}

Liver samples of infected and control animals were embedded in LR Gold resin and ultra-thin sections were placed on gold grids. The sections were incubated with anti-hepatitis $\mathrm{C}$ core antibody (1:5 dilution), NS5A monoclonal antibody (Virogen, 1:10 dilution) and with an anti-hepatitis C E1, E2, NS3, NS4 polyclonal antibody (Oxford Technology, 1:10 dilution) using a buffer containing $0.2 \mathrm{M}$ Tris $\mathrm{HCl} \mathrm{pH} 8.2, \mathrm{NaCl} 150$ $\mathrm{mM}$, fish gelatin $0.1 \%, 0.5 \%$ Tween 20 , bovine serum albumin $1 \%$ at $37^{\circ} \mathrm{C}$ for 1 hour. The grids were then washed with distilled water and incubated again with $10 \mathrm{~nm}$ colloidal gold linked protein-A solution in $0.2 \mathrm{M}$ Tris $\mathrm{HCl} \mathrm{pH} 8.2, \mathrm{NaCl} 150 \mathrm{mM}$, fish gelatin $0.1 \%, 0.5 \%$ Tween 20 , bovine serum albumin $1 \%$ at $37^{\circ} \mathrm{C}$ for 1 hour. The grids were then washed with distilled water, stained with a $2 \%$ aqueous solution of uranyl acetate for 10 minutes, dried, and examined with a Zeiss EM-900 electron microscope. 


\section{RESULTS}

The biopsy samples of the animal intrasplenically inoculated using the autogenic hepatocyte transplant methodology infected with HCV were taken at two different time intervals (57 days and 4 months). Morphological analysis was executed in order to detect and localize HCV RNA and proteins.

Completely disorganized focal areas in the liver parenchyma were observed at 57 days p.i. using light microscopy and semi-thin sections. The cytoplasm of hepatocytes was strongly vacuolated and rarefied. At four months p.i., hepatocytes in the damaged areas became rounded and swollen; some picnotic nuclei occurred; the cell membrane was apparently discontinuous, and the typical regular sinusoidal cell disposition was lost. Ultrastructural observations of Epon-embedded infected liver sections showed a membranous web and dilated rough endoplasmic reticulum (rER), vesicles and cysterns surrounding mitochondria (Fig.1).

Electron microscopy in situ hybridization showed that gold labelling was consistently found over the rER membranes (Fig. 2) and over vesicles which proliferate during HCV infection inside the rER cysterns (Fig. 3), using the positive strand probe (K16). Using the negative strand probe (K15), the labelling was found over the membranes of dilated rER cysterns surrounding mitochondria (Fig. 4) The negative control material, which consisted of liver biopsies from an animal transplanted with non-infected hepatocytes, did not showed any specific labelling.

The immuno-EM labelling obtained with a monoclonal antibody against the core protein showed gold particles accumulated on membranes of dilated vesicles of the rER surrounding mitochondria and on the outer membrane of mitochondria (Figs. 5, 6). Similar findings were observed using a polyclonal antibody against NS3, NS4, E1, E2 proteins (Fig. 7), and with a NS5A-specific label (Fig. 8). 

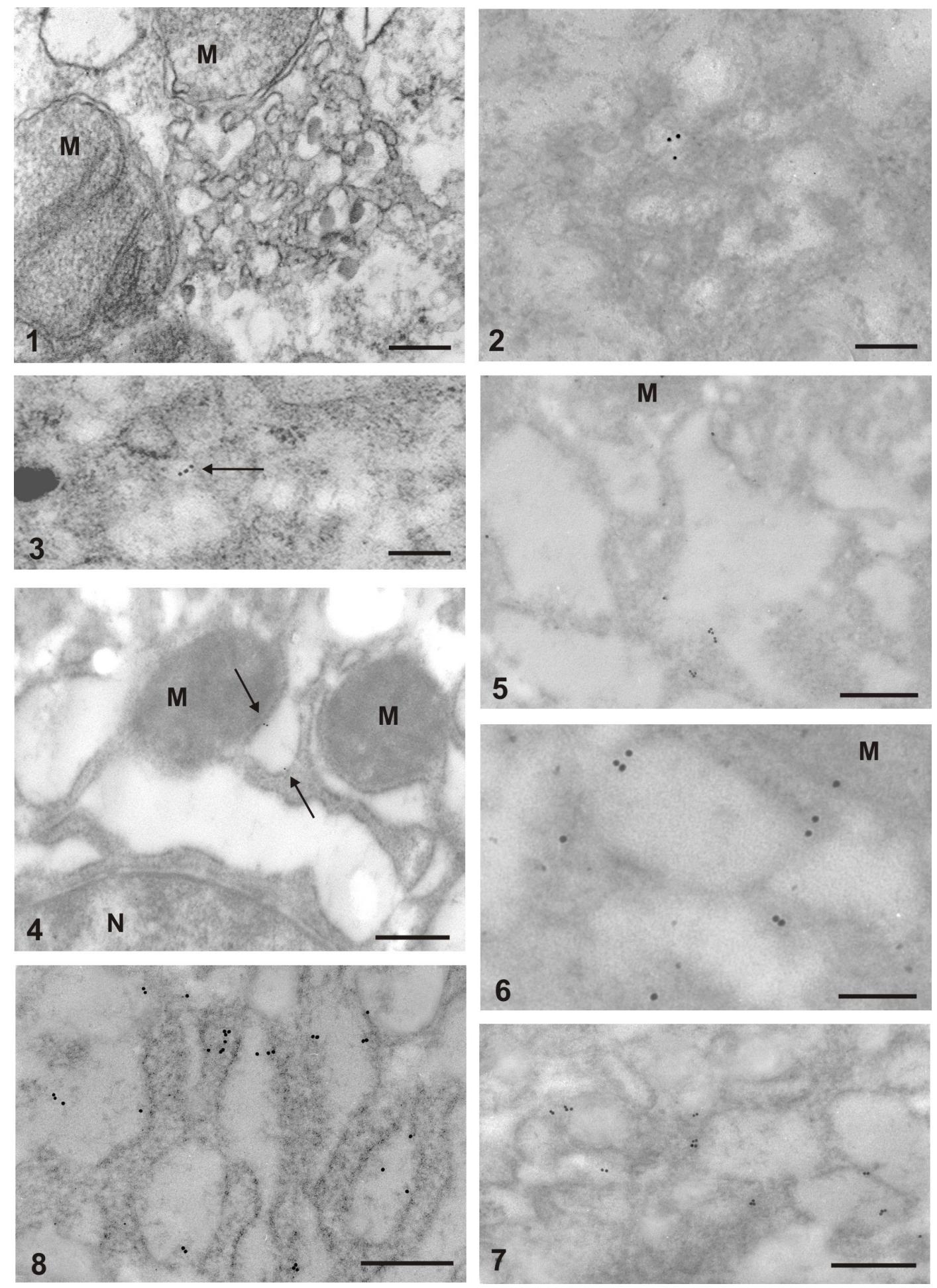
Figure 1. Liver biopsy of a rhesus macaque infected with HCV at four months p.i. Liver sample embedded in Epon shows alterated membranes of the rER membranous web and vesicles, besides mitochondria (M). Bar $=200 \mathrm{~nm}$. Figure 2. In situ hybridization using a digoxigenin-labelled positive strand probe (K16). The gold particles demonstrate the presence of the negative HCV strand RNA on the membranous web. Bar $=300 \mathrm{~nm}$. Figure 3. The same preparation as in Figure 2. Gold particles (arrow) are laying over a smooth vesicle inside a rER cystern. Bar $=300 \mathrm{~nm}$. Figure 4. HCV-infected hepatocyte using in situ hybridization. The label (K15 probe) shows gold particles (arrows) on the membranes of the dilated rER in close association with mitochondria $(\mathrm{M})$ and the cell nucleus $(\mathrm{N})$. Bar $=500 \mathrm{~nm}$. Figure 5. Immunogold analysis of core protein labelled with a core-specific monoclonal antibody. Gold label was detected on dilated $\mathrm{rER}$ vesicles in vicinity of mitochondria. Bar $=300 \mathrm{~nm}$. Figure 6. Immunogold analysis of core protein labelled with a core-specific monoclonal antibody. Gold particles were detected on rER cystern membranes and on the outer membrane of a mitochondrium. Bar $=300 \mathrm{~nm}$. Figure 7. Hepatocyte labelled with a polyclonal antibody against HCV proteins E1, E2, NS3 and NS4. Gold particles are present on membranes of rER vesicles. Bar $=300 \mathrm{~nm}$. Figure 8. Immunolabelling of HCV NS5 protein showing gold particles on membranes of rER cysterns. Bar $=300 \mathrm{~nm}$.

\section{DISCUSSION}

We previously reported the morphological changes of rhesus hepatocytes caused by $\mathrm{HCV}$ infection, when patches of microtubuloreticular aggregates were observed inside the hepatocytes cytoplasm (Barth et al. 2003). Similar structures were observed also by Pfeiffer et al. (1980) in hepatocytes of HCV-infected chimpanzees by expression of the HCV structural proteins from a SFV recombinant RNA replicon (Greive et al. 2002) and by Egger et al. (2002) in a HCV infected tetracycline-regulated cell line.

Positive RNA labelling was observed at both time intervals and with both molecular probes, when the hepatocytes showed an increase in rER and vesicle formation. However, the labelling pattern shown by each of the dig-labelled probes was occasionally found to be rather different. Thus in the case of K16, which is the positive strand probe, labelling was more frequently localized over associated rER membranes and over vesicles which proliferate during HCV infection inside the rER cysterns (Figs. 2, 3). It is most likely that the K16 probe detected the presence of the replication intermediate negative strand viral RNA. The location of this intermediate replication form could represent the site of the HCV replication center within the liver cell. In the case of $\mathrm{K} 15$, the negative complementary strand probe, the gold labelling was consistently found over the membranes of dilated rER cysterns surrounding 
mitochondria (Fig. 4), and was detected over alterated membranes of the rER (Majerowicz et al. 2004) together with the K16 probe also.

The present investigation using EM-immuno labelling localized the core and the NS HCV proteins in membranes of cysterns and vesicles of the rER in infected rhesus monkey liver biopsies. Our results are in accordance with previous studies that detected HCV proteins in human and chimpanzee liver biopsies (Barba et al. 1997, Falcón et al. 2003, Kasprzak et al. 2005) and in genetically modified cell systems expressing subgenomic HCV replicons (Egger et al. 2002, Mottola et al. 2002, Gosert et al. 2003).

We observed the core protein also on the outer membrane of mitochondria, as described by Kasprzak et al. (2005), Okuda et al. (2002) and Schwer et al. (2004). It has been suggested that the localization of $\mathrm{HCV}$ core protein on mitochondria would be a good position to encapsidate HCV RNA released from the replication complex and that core protein may alterate the mitochondrial function, changing the cellular physiology to favor viral replication (Schwer et al. 2004). Moreover, the viral RNA was also observed, in our study, frequently on dilated rER cysterns close to mitochondria. It has been known that there is a contact site between rER and mitochondria (Rizzuto et al. 2000, Csordás et al. 2006), providing the condition to control ER-derived $\mathrm{Ca}^{2+}$ signal distribution to the mitochondria (Hajnóczky et al. 2000) and the activity of apoptotic proteins in the ER (Walter \& Hajnóczky 2005).

The absence of any clearly defined virus particle in our EM specimens may be explained by the fact that this virus replicates very slowly and that the number of virus particles is likely to be very low making detection very difficult. Few virus-like particles were observed in cytoplasmic vesicles of human (Bosman et al. 1998, Falcón et al. 2003) and chimpanzee (Shimizu et al. 1996) hepatocytes. These authors concluded that $\mathrm{HCV}$-positive cells in a liver tissue are very rare and difficult to be detected using electron microscopy.

The positivity of HCV replication was provided in the present study by the development of a more accurate diagnostic tool to $\mathrm{HCV}$ infection which improved the access to viral genome in liver samples.

In conclusion, the in situ hybridization and immunolabelling at the ultrastructural level of resolution has enabled the clear localization of HCV RNA and viral proteins in hepatocytes of a rhesus monkey, which has been previously challenged with a strain of the HCV. It provides important information about the nature of in vivo 
intracellular HCV replication in rhesus hepatocytes and supports the previous positive PCR results, confirming that this particular monkey was infected with HCV.

\section{ACKNOWLEDGEMENTS}

We thank to Bárbara Rodrigues dos Santos and José Mariano da Silva for excellent technical assistance. Financial support was given to the last author by the Nacional Council for Scientific and Technological Development (CNPq), Brazil.

\section{REFERENCES}

Barba G, Harper F, Harada T, Kohara M, Goulinet S, Matsuu Y, Ede RG, Schaff ZS, Chapman, MJ, Miyamura T, Bréchot C 1997. Hepatitis C core protein shows a cytoplasmic localization and associates to cellular lipid storage droplets. Proc. Natl. Acad. Sci. 94: 1200-1205.

Bartenschlager R, Lohmann V 2000. Replication of the hepatitis C virus. Baillière's Clinical Gastroenterology 14, 241-254.

Barth OM, Majerowicz S, Vitral CL, Yoshida CFT, Schatzmayr HG 2003. Ultrastructure of hepatocytes of a rhesus monkey infected with hepatitis $\mathrm{C}$ virus. Virus Rev. Res. 8: 29-34.

Bosman C, Valli MB, Bertolini L, Serafino A, Boldrini R, Marcellini M, Carloni G 1998 Detection of vírus-like particles in liver biopsies from HCV-infected patients. Res. Virol. 149: 311-314.

Chang M, Marquardt AP, Wood BL, Williams O, Cotler SJ, Taylor SL, Carithers RL, Gretch DR 2000. In situ distribution of hepatitis C virus replicative-intermediate RNA in hepatic tissue and its correlation with liver disease. J. Virol. 74: 944-955.

Choo Q-L, Kup G, Weiner AJ, Overby LR, Bradley DW, Houghton M 1989. Isolation of a cDNA clone derived from a blood-borne non-A, non-B viral hepatitis genome. Science 244: 359-362. 
Csordás G, Renken C, Várnai P, Walter L, Weaver D, Buttle KF, Balla T, Mannella CA, Hajnóczky G 2006. Structural and function features and significance of the physical linkage between ER and mitochondria. J. C. B. 174: 915-921.

Debuisson J, Penin F, Moradpour D 2002. Interaction of hepatitis C virus proteins with host cell membranes and lipids. Trends in Cell Biology 12: 517-523.

Egger D, Wolk B, Gosert R, Bianch I L, Blum HE, Moradpour D, Bienz K 2002. Expression of hepatitis $\mathrm{C}$ virus proteins induces distinct membrane alterations including a candidate viral replication complex. J. Virol. 76: 5974-5984.

Falcón V, Acosta-Rivero N, Chinea G, Gavilondo J, de la Rosa M-C, Menéndez I, Duenãs-Carrera S, Vinã A, García W, Grã B, Noa M, Reytor E, Barceló MT, Alvarez F, Morales-Grillo J 2003. Ultrastructural evidences of HCV infection in hepatocytes of chonically HCV-infected patients. Biochem. Biophys. Res. Commun. 305: 1085-1090.

Gastaldi M, Massacrier A, Planells R, Robaglia-Schlupp A, Portal-Bartolomei I, Bourliére M, Quilici F, Fiteni J, Mazzella E, Cau P 1995. Detection by in situ hybtidization of hepatitis $\mathrm{C}$ virus positive and negative RNA strands using digoxigeninlabeled cRNA probes in human liver cells. J. Hepatol. 23: 509-511.

Gosert R, Egger D, Lohmann V, Bartenschlager R, Blum HE, Bienz K, Moradpour D 2003 Identification of the hepatitis C virus RNA replication complex in Huh-7 cells harboring subgenomic replicons. J. Virol. 77: 5487-5492.

Greive SJ, Webb RI, Mackenzie JM, Gowans EJ 2002. Expression of the hepatitis C virus structural proteins in mammalian cells induces morphological similar to that in natural infection. J. Vir. Hepat. 9: 9-17.

Grief C, Farrar GH, Kent KA, Berger EG 1991. The assembly of HIV within the Golgi apparatus and Golgi derived vesicles of JM cell syncytia. AIDS 5: 1433-1439. 
Grief C, Galler R, Côrtes LMC, Barth OM 1997. Intracellular localisation of dengue-2 RNA in mosquito cell culture using electron microscopic in situ hybridisation. Arch. Virol. 142: 2347-2357.

Hajnóczky G, Csordás G, Madesh M, Pacher P 2000. The machinery of local $\mathrm{Ca}^{2+}$ signaling between sarco-endoplasmic reticulum and mitochondria. J. Phys. 529: 69-81

Houghton M. 1996. Hepatitis C viruses. In: NB Fields, DM Knipe, PM Howley et al. (eds). Virology, $3^{\text {rd }}$ ed., Lippoincott-Raven Publishers, Philadelphia p. 1035-1058.

Kasprzak A, Seidel J, Biczysko W, Wysocki J, Apachacz R, Zabel M 2005. Intracellular localization of NS3 and C proteins in chronic hepatitis C. Liver International 25: 896903.

Lamas E, Baccari P, Housset C, Kremsdorf D, Bréchot C 1992. Detection of hepatitis C virus (HCV) RNA sequences in liver tissue by insitu hybridization. J. Hepatol. 16: 219223.

Lohmann V, Körner F, Koch J-O, Herian U, Theilmann L, Bartenschlager R 1999. Replication of subgenomic hepatitis C virus RNAs in a hepatoma cell line. Science 285: 110-113.

Majerowicz S, Grief C, Ferguson D, Airano RC, Baptista ML, Pinto MA, Barth OM 2004. In situ hybridization of hepatitis C virus RNA in liver cells of an experimentally infected rhesus macaque.Mem. Inst. Oswaldo Cruz 99: 629-631.

Moradpour D, Gosert R, Egger D, Penin F, Blum HE, Bienz K 2003. Membrane association of hepatitis $\mathrm{C}$ virus nonstructural proteins and identification of the membrane alteration that harbors the viral replication complex. Antiviral Res. 60: 103109 
Moradpour D, Brass V, Bieck E, Frieb P, Gosert R, Blum HE, Bartenschlager R, Penin F, Lohmann V 2004. Membrane association of the RNA-dependent RNA polymerase is essential for hepatitis c virus RNA replication. J. Virol. 78: 13278-13284.

Mottola G, Cardinali G, Ceccaci A, Trozzi C, Bartholomew L, Torrisi MR, Pedrazzini E, Bonatti S, Migliaccio G 2002. Hepatitis C virus nonstructural proteins are localized in a modified endoplasmic reticulum of cells expressing viral subgenomic replicons. Virology 293: 31-43.

Negro F, Pacchioni D, Shimizu Y, Miller RH, Bussolati G, Purcell RH, Bonino F 1992. Detection of intrahepatic replication of hepatitis C virus RNA by in situ hybridization and comparison with histopathology. Proc. Natl. Acad. Sci. 89: 2247-2251.

Novoa RR, Calderita G, Arranz R, Fontana J, Granzow H, Risco C 2005. Virus factories: associations of cell organelles for viral replication and morphogenesis. Biol. Cell 97: 147-172.

Nouri-Aria KT, Sallie R, Sangar D, Alexander GJ, Smith H, Byrne J, Portmann B, Eddleston AL, Williams R 1993 Detection of genomic and intermediate replicative strands of hepatitis $\mathrm{C}$ virus in liver tissue by in situ hybridization. J. Clin. Invest. 91: 2226-2234.

Okuda M, Li K, Beard MR, Showalter LA, Scholle F, Lemon SM, Weinman SA 2002. Mitochondrial injury, oxidative stress, and antioxidant gene expression are induced by hepatitis C virus core protein. Gastroenterology 122: 366-375.

Pawlotsky J-M 2004. Pathophysiology of hepatitis C virus infection and related liver disease.Trends Microbiol. 12: 96-102.

Penin F, Debuisson J, Rey FA, Moradpour D, Pawlotsky J-M 2004. Structural biology of hepatitis C virus. Hepatology 39: 5-19. 
Pfeifer U, Thonssen R, Legler K, Bottcher U, Gerlich W, Weimmann E, Klinge O 1980. Experimental non-A, non-B hepatitis: four types of cytoplasmic alteration in hepatocytes of infected chimpanzees. Virchow Arch. B Cell. Pathol. 33: 233-243.

Pietschmann T, Lohmann V, Rutter G, Kurpanek K, Bartenschlager R 2001. Characterization of cell lines carrying self-replicating hepatitis C virus RNAs. J. Virol. 75: $1252-1264$.

Pietschmann T, Lohmann V, Kaul A, Krieger N, Rinck G, Rutter G, Strand D, Bartenschlager R 2002. Persistent and transient replication of full-length hepatitis C virus genomes in cell culture. J. Virol. 76: 4008-4021.

Quadri R, Rubbia-Brandt L, Abid K, Negro F 2001. Detection of the negative-strand hepatitis C virus RNA in tissues: implications for pathogenesis. Antiviral Res. 52: 160171.

Rizzuto R, Bernardi P, Pozzan T 2000. Mitochondria as all-round players of the calcium game. J. Physiol. 529: 37-47.

Salonen A, Ahola T, Kääriäinen L 2004. Viral RNA replication in association with cellular membranes. CTMI 285: 139-173.

Sansonno D, Cornacchiulo V, Racanelli V, Dammacco F 1997. In situ simultaneous detection of hepatitis $\mathrm{C}$ virus RNA and hepatitis $\mathrm{C}$ virus-related antigens in hepatocellular carcinoma. Cancer 80: 22-33.

Schwer B, Ren S, Pietschmann T, Kartenbeck J, Kaehlcke K, Bartenschlager R, Yen TSB, Ott M 2004. Targeting of hepatitis C virus core protein to mitochondria through a novel c-terminal localization motif. J. Virol. 78: 7958-7968.

Shimizu YK, Feinstone SM, Kohara M, Purcell RH, Yoshikura H 1996. Hepatitis C virus: detection of intracellular virus particles by electron microscopy. Hepatology 23: 205-209. 
Shimizu YK, Igarashi H, Kiyohara T, Shapiro M, Wong DC, Purcell RH, Yoshikura H 1998. Infection of a chimpanzee with hepatitis c virus grown in cell culture. J. Gen. Virol. 79: 1383-1386.

Walter L, Hajnóczky G 2005. Mitochondria and endoplasmic reticulum: the letal interorganelle cross-talk. J. Bioenerg. Biomembr. 37: 191-206.

Yuki N, Matsumoto S, Tadokoro K, Mochizuki K, Kato M, Yamaguchi T 2006. Significance of liver negative-strand HCV RNA quantitation in chronic hepatitis C. $J$. Hepatol. 44: 302-309. 